\title{
Synchronization of the life cycle and dispersal pattern of the tropical invader scyphomedusan Rhopilema nomadica is temperature dependent
}

\author{
A. Lotan*, M. Fine, R. Ben-Hillel \\ Department of Zoology, Tel Aviv University, Ramat Aviv, 69978 Tel Aviv, Israel
}

\begin{abstract}
During the last decade, an Indo-Pacific scyphomedusa, Rhopilema nomadica, penetrated the eastern Mediterranean. Annual blooms of the medusa near the Israeli coast were observed during the summer months of the years 1989 to 1992. R. nomadica migrated northward from the Israeli coast towards Lebanon and Syria and has not been found elsewhere in the Mediterranean. Temperature dependence of the metamorphosis of $R$. nomadica polyps into strobila was studied in the laboratory. Rapid strobilation occurred between 18 and $20^{\circ} \mathrm{C}$, and a decline of strobilation was observed when the temperature was raised to 24 or $26^{\circ} \mathrm{C}$. When water temperature was below $16^{\circ} \mathrm{C}$, polyps did not strobilate, and below $13^{\circ} \mathrm{C}$, polyps did not feed, resulting in a gradual loss of polyp vitality. Comparison of the temperature regime in the Levant Basin and the dependence of polyp strobilation on temperature suggest that the spring rise in water temperature causes a rapid strobilation, whereas winter and summer water temperatures inhibit or diminish reproduction. Laboratory studies support the possibility that synchronization and annual occurrence of $R$. nomadica is controlled by seasonal changes in water temperature regimes, leading to rapid strobilation and release of ephyrae during springtime. The sensitivity of the polyps to low temperatures enables us to predict that the future dispersal of Rhopilema nomadica may be limited to the eastern Mediterranean. This study emphasizes the importance of the effect of 1 abiotic factor on the physiology and the migration pattern of $R$. nomadica. This can be a good model for understanding the behavior and limiting factors of Indo-Pacific jellyfish migrating into non-tropical seas.
\end{abstract}

KEY WORDS: Scyphomedusa $\cdot$ Dispersal $\cdot$ Bloom $\cdot$ Strobilation

\section{INTRODUCTION}

The occurrence of medusae blooms in the Mediterranean has been known for a long time. Aggregations of Pelagia noctiluca were recorded along the western and central parts of the Mediterranean, in the Ligurian and Adriatic Seas (Zavodnik 1987, Goy et al. 1989, Axiak et al. 1991). Blooms of $P$. noctiluca were recorded every 12 th year for the past 200 yr (Goy et al. 1989). These blooms were positively correlated with changes in several climatic variables that may have enhanced primary production, which in turn led to proliferation of the $P$. noctiluca populations.

\footnotetext{
-Present address: Dept of Cell and Animal Biology, Institute of Life Sciences, Hebrew University of Jerusalem, Jerusalem 91904, Israel
}

Positive correlation between pollution and swarming of jellyfish was also found for Rhizostoma pulmo in the coastal waters of Mersine Bay, Turkey (Bingel et al. 1991), and for Aurelia aurita in the Aegean Sea (Wilkerson \& Dugdale 1983). These findings suggest that jellyfish blooms may be caused by the ability of medusae to utilize plankton blooms produced by pollution-caused eutrophication (Legovic 1987), or by their ability to utilize pollutants directly as food (Muscatine \& Matian 1982).

Annual swarming of scyphomedusae has previously been correlated both with temperature and nutrition. The life cycle of scyphozoans includes a benthic polyp stage that reproduces asexually and releases ephyrae, and a planktonic medusa stage that reproduces sexually. Optimal strobilation of Aurelia aurita on the Swedish coast was observed during autumn, when zoo- 
plankton biomass peaked (Hernroth \& Grondahl 1983, 1985). Strobilation of Rhopilema esculenta in China, though dependent on nutrition, was delayed or inhibited when water temperature fell below $15^{\circ} \mathrm{C}$ (Chen \& Ding 1984, Chen et al. 1985). In a similar manner, onset of strobilation by the Atlantic species Cyanea sp. and Chrysaora quinqueciriha was triggered by raising the water temperature above $15^{\circ} \mathrm{C}$ (Calder 1974, Brewer 1989). Temperature thus appears to synchronize the annual appearance of some jellyfish species.

In the eastern Mediterranean, 7 scyphomedusan species were reported from the coasts of Israel, Lebanon, Turkey and Greece (Wilkerson \& Dugdale 1983, Galil et al. 1990, Bingel et al. 1991, Lakkis 1991). Large fluctuations in the jellyfish populations were found in the coastal waters of Lebanon during 1971-1986. These fluctuations were related to specific environmental factors that led to increased production of phyto- and zooplankton (Lakkis 1991).

In 1977, several specimens of an Indo-Pacific jellyfish species were observed along the Mediterranean coast of Israel. The species was determined as Rhopilema nomadica (Galil et al. 1990). Summer aggregations of this species have been observed along the Israeli coast since 1986 . In recent years large aggregations of $R$. nomadica, some reaching 160000 specimens $\mathrm{km}^{-2}$, were recorded at different localities along the Israeli coast (Lotan et al. 1992). These 'population explosions' of $R$. nomadica have both environmental and economic consequences, including injury to bathers, damage to tourism, and reduced fishing harvests due to clogging of fishing nets (Lotan et al. 1992).

The present study determined the micro- and macrodistribution of Rhopilema nomadica in the Mediterranean, specifically aiming to correlate the spatial and temporal occurrence of this species with environmental factors expected to affect its distribution. We conducted surveys and field monitoring of medusae blooms along the Mediterranean coast, and laboratory experiments to determine the effects of temperature on reproduction and vitality of $R$. nomadica polyps. The prognosis for the future dispersal of $R$. nomadica in the Mediterranean and the influence of temperature on invasions of tropical scyphomedusae are discussed.

\section{MATERIALS AND METHODS}

Determination of density and dispersal of the medusae. Monitoring for localized swarms of Rhopilema nomadica along the $225 \mathrm{~km}$ of the Israeli coast was conducted during May-September 1989. The count was taken at a distance of $1 \mathrm{~km}$ offshore. The Israeli coast was divided into 9 sections of $25 \mathrm{~km}$ each. In every section, 5 transects were conducted twice a month. The average number of medusae was calculated from the total of 450 transects examined during this period.

Haifa Bay, located in the northern part of the Israeli coast, was sampled weekly during June of 1989 to May of 1990 . The bay was sampled in 3 areas: north, center and south. In each area 3 grids of $1.8 \mathrm{~km}^{2}$ were examined. The average number of medusae during this period in Haifa Bay was calculated from the total of 455 transects. Weekly sampling in Haifa Bay was also carried out during June-October for 3 consecutive years (1990 to 1992 ).

The number of medusae along a $1.8 \mathrm{~km}$ (1 nautical mile) transect was counted. The boat sailed at a constant speed of $3 \mathrm{~m} \mathrm{~s}^{-1}$. Counting was done from a fixed place at the front of the sampling boat, and the medusae within $10 \mathrm{~m}$ of each side of the boat were counted. Dense concentrations of medusae ( $>2$ specimens $\mathrm{m}^{-2}$ ) were counted under a $1.5 \mathrm{~m}$ stick to a depth of ca $2 \mathrm{~m}$. Some Rhopilema nomadica were collected by hand nets, and the bell diameter was measured on the boat to the nearest $\mathrm{cm}$ (the sample size, N, was 16 to 49 specimens).

In order to determine the full range of distribution of Rhopilema nomadica in the Mediterranean Sea, questionnaires including a detailed description and photograph of the medusa were distributed through the auspices of MED POL (Mediterranean Action Plan, United Nations Environment Programme) to marine stations of countries bordering the Mediterranean Sea.

Laboratory experiments with polyps. Rhopilema nomadica polyps were cultured in aquaria as described in Lotan et al. (1992). The polyps were taken from a stock culture which was kept at a constant temperature of $22^{\circ} \mathrm{C}$, with $12 \mathrm{~h}$ of illumination per day. Polyps were transferred directly into petri dishes with $30 \mathrm{ml}$ of filtered seawater. The dishes were maintained under the same light regime, with $12 \mathrm{~h}$ of illumination per day, but kept in incubators at different temperatures ranging between 11 and $26^{\circ} \mathrm{C}$ for a period of $6 \mathrm{wk}$. Polyps were fed twice a week with newly hatched nauplii of Artemia sp. (Sanders Brine Shrimp Eggs), and after $12 \mathrm{~h}$ the remnants of the Artemia were removed, keeping the same water. Three replicate series of petri dishes, each containing 8 polyps, were tested for each temperature. Survival, polyp strobilation and ephyrae released were recorded. For each parameter mean $\pm \mathrm{SD}$ was calculated. Percentage of polyp strobilation. at different temperatures were arc-sine transformed and compared by using 1-way ANOVA followed by the a posteriori test (Sokal \& Rohlf 1969).

Mean temperatures in the Mediterranean. Data on mean winter Mediterranean water temperatures are from the Master Generalized Digital Environmental Model (Naval Oceanographic Office 1989). Data on mean Israeli coastal temperatures (measured during 1947 to 1968) are from Oren \& Hornung (1972). 


\section{RESULTS AND DISCUSSION}

\section{Annual occurrences of Rhopilema nomadica along the Israeli coast}

Study of the distribution pattern of Rhopilema nomadica along the coast of Israel was conducted during summer 1989. Significant accumulations of the medusa were observed in the northern region of Israel, and the highest concentration was monitored at Haifa Bay (Fig. 1). This high aggregation could be a result of current regimes and water movements (Zavodnik 1987), or of a high concentration of nutrients in Haifa Bay (Wilkerson \& Dugdale 1983).

Aggregation of Rhopilema nomadica in Haifa Bay was studied for an entire year in 1989-1990. Dense aggregations of the jellyfish were observed during the summer (Fig. 2). The highest concentrations were counted during July and August. The large standard deviation (Fig. 2) was due to differences in local concentrations of medusae in the north, center and south of Haifa Bay as described in Lotan et al. (1992), and was not related to changes in the total number of jellyfish during July and August.

Summer aggregation of Rhopilema nomadica was studied in Haifa Bay during the years 1989 to 1992 (Table 1). Concentrations of jellyfish during these years showed little variation. High similarity in date of initial occurrence, always in the second half of June, was observed. The population peaked at the beginning of August (see Fig. 2), and the last specimens were seen between September and November.

\section{Strobilation and vitality of Rhopilema nomadica polyps under different temperature regimes}

The similarity of occurrence and bell diameter of Rhopilema nomadica during 4 consecutive years suggests the presence of a strong controlling mechanism

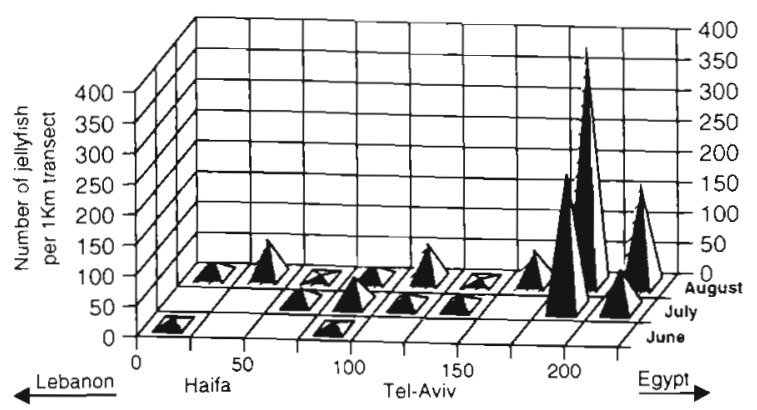

Fig. 1. Rhopilema nomadica. Occurrence during the summer of 1989 . The abscissa represents $225 \mathrm{~km}$ of the Israeli coast. Each square represents an average of 10 transects

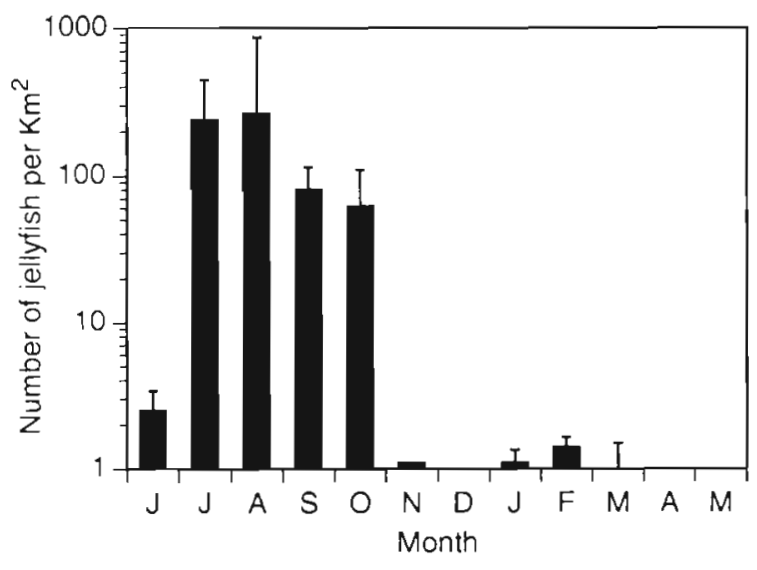

Fig. 2. Rhopilema nomadica. Concentration in Haifa Bay during June 1989 to May 1990. N = 455 transects

which synchronizes the population dynamics of this species. Nutrient enrichment and temperature are the 2 most important factors previously shown to be implicated in synchronization of jellyfish populations. Large nutrient enrichment and high primary production occurs in Haifa Bay during the winter (Azov 1991), when few jellyfish were recorded (see Fig. 2). Therefore, temperature as a controlling factor in strobilation was tested. The temperature regimes selected for incubation of the polyps reflected both the temperature range prevailing in the Mediterranean and its duration. The minimum winter temperature is $11^{\circ} \mathrm{C}$ in the Adriatic Sea, and the maximum summer temperature is $28.5^{\circ} \mathrm{C}$ in the Levant Basin (Eastern Mediterranean). The ability of polyps to survive different temperatures as well as the influence of these temperatures on asexual reproduction were examined.

Polyps were incubated for $6 \mathrm{wk}$ at constant temperatures ranging between 11 and $26^{\circ} \mathrm{C}$. All the polyps survived during the experiment, except polyps which were incubated at temperatures less than $13^{\circ} \mathrm{C}$. Polyps maintained at temperatures between 11 and $13^{\circ} \mathrm{C}$ for a period of $2 \mathrm{wk}$ did not feed, and some polyps lost their vitality. These polyps became white or transparent and shrank to less than $25 \%$ of their original size. This result is similar to that reported by Chen et al. (1985) for Rhopilema esculenta.

Polyps kept at 14 or $16^{\circ} \mathrm{C}$ showed minimal strobilation throughout the $6 \mathrm{wk}$ period of the incubation experiment (Fig. 3a). Strobilations increased significantly ( $p<0.001$ ) when the polyps were subjected to a temperature of $18^{\circ} \mathrm{C}$. Further elevation of the temperature reduced the time lag before onset of strobilation from 6 to $8 \mathrm{~d}$ at $18^{\circ} \mathrm{C}$ to 4 to $6 \mathrm{~d}$ at $22^{\circ} \mathrm{C}$, but did not increase the percentage of strobilating polyps (see Fig. 3a). Strobilation peaked between 18 and $22^{\circ} \mathrm{C}_{i}$ at these temperatures more than $50 \%$ of the polyps were strobilated. Further increases of the tem- 
Table 1. Rhopilema nomadica. Population densities, size and occurrence in Haifa Bay, Israel

\begin{tabular}{|ccccc}
\hline Year & $\begin{array}{c}\text { Mean size }(\mathrm{cm}) \\
\pm \mathrm{SD}(\mathrm{N})^{\mathrm{a}}\end{array}$ & $\begin{array}{c}\text { Population density } \\
\left(\text { no. } \times 10^{3} \mathrm{~km}^{-2}\right)\end{array}$ & $\begin{array}{c}\text { Date of first } \\
\text { observation }\end{array}$ & $\begin{array}{c}\text { Date of last } \\
\text { observation }\end{array}$ \\
\hline 1989 & $19.0 \pm 7.0(49)$ & $165 \pm 46$ & 27 June & 12 November \\
1990 & $16.0 \pm 3.0(16)$ & $140 \pm 20$ & 21 June & 13 September \\
1991 & $19.0 \pm 5.0(20)$ & $102 \pm 20$ & 24 June & Not detected \\
1992 & $24.0 \pm 7.0(18)$ & $152 \pm 70$ & 27 June & 2 September
\end{tabular}

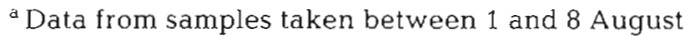
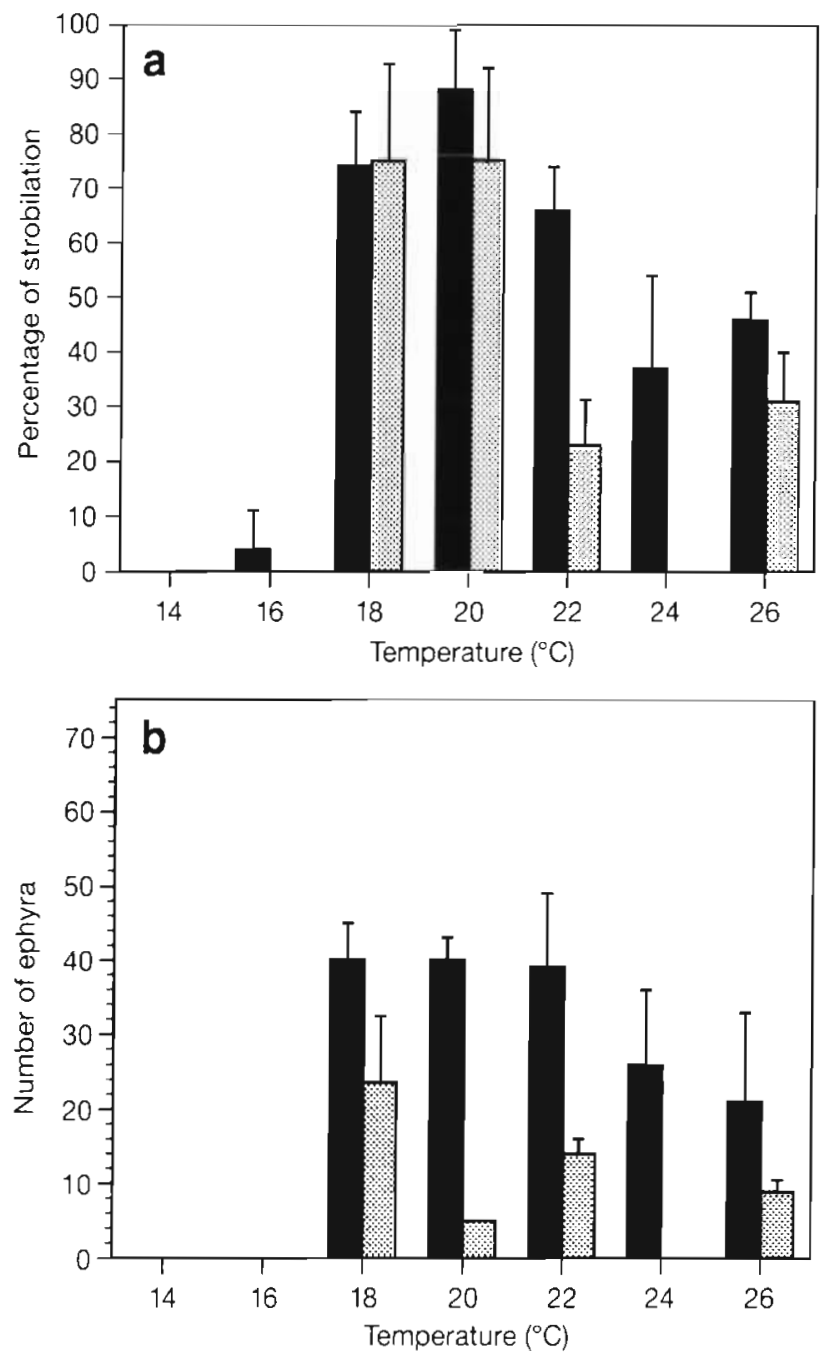

Fig. 3. Rhopilema nomadica. (a) Polyp strobilation under different temperature regimes. Black bars: percentage of polyps that entered into strobilation within 6 to $10 \mathrm{~d}$. Shaded bars: percentage of polyps that began a second strobilation after 24 to $40 \mathrm{~d}$. (b) Number of released ephyrae under different temperature regimes. Black bars: Average number of ephyrae released at the first strobilation (6 to $10 \mathrm{~d}$ ). Shaded bars: Average number of ephyrae released at the second strobilation (24 to $40 \mathrm{~d}$ ). Results are the mean value of 3 replicates, each with 8 polyps at each temperature perature to 24 or $26^{\circ} \mathrm{C}$ significantly decreased $(p<0.001)$ strobilation rates (Fig. 3a). Under favorable temperature and nutritional conditions, polyps of Rhopilema nomadica enter second and even third strobilations (Lotan et al. 1992, Fig. 3a). The percentage of strobilating polyps and the number of released ephyrae decreased in the second strobilation (Fig. 3). All these results show dependence of polyp metamorphosis and reproduction on temperature.

The success of asexual reproduction is dependent not only on the strobilation process, but also on the number of ephyrae released (Hernroth \& Grondahl 1983). A maximum of 5 or 6 ephyrae are formed per strobila of Rhopilema nomadica under optimal conditions (Lotan et al. 1992). Water temperatures did not change the number of the ephyrae produced by each polyp during the first strobilation (Fig. 3b). Therefore these results indicate that the strobilation process, rather than the number of the ephyrae on each polyp, is controlled by the water temperature.

The Israeli coastal shelf is characterized by high water temperature in the summer $\left(25\right.$ to $28.5^{\circ} \mathrm{C}$, June to October) followed by a significant decrease during winter $\left(16^{\circ} \mathrm{C}\right.$, March). A quick warming of coastal waters occurs during spring $\left(18\right.$ to $20^{\circ} \mathrm{C}$, April) (Oren \& Hornung 1972, Fig. 4). The laboratory findings suggest that strobilation in the field should be inhibited by low winter temperatures and that the rise in temperatures during the spring should trigger the onset of synchronous strobilation in the polyps. Release of ephyrae within a short period at the beginning of spring (Fig. 4) would then explain the synchronous annual aggregation bloom of the medusae in July-August. This is based on the assumption that ephyrae released from polyps during spring (diameter of $2 \mathrm{~mm}$, Lotan et al. 1992), develop into mature medusae of $170 \mathrm{~mm}$ within $3 \mathrm{mo}$ (see Table 1). This assumption is supported by findings on rapid growth in other jellyfish species. For example, Aurelia aurita in the Kiel Fjord grow from $2 \mathrm{~mm}$ ephyrae to $156 \mathrm{~mm}$ medusae in 3 mo (April to July) (Möller 1980); and Chrysaora quinquecirrha in the laboratory increased in size at a rate of $10 \% \mathrm{~d}^{-1}$ (Larson 1986). Cyanea sp. in the Niantic River doubled in size in only $12 \mathrm{~d}$ (Brewer 1989).

\section{Distribution of Rhopilema nomadica in the eastern Mediterranean}

Rhopilema nomadica was first reported along the Israeli Mediterranean coast in 1977. Ten years later, large aggregations of this jellyfish were a familiar sum- 


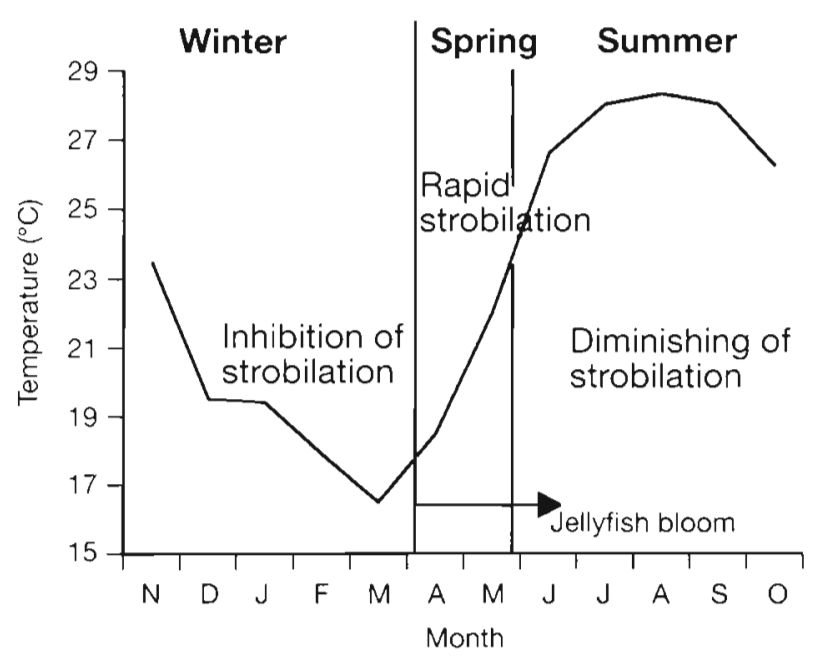

Fig. 4. Suggested model for the summer bloom of Rhopilema nomadica, showing time of strobilation. Curve represents surface water temperature during the year along the Israeli coast (Oren \& Hornung 1972)

mer phenomenon. $R$. nomadica was not reported during the same period near the Lebanese and the Turkish coasts. This raises the question of whether migration of $R$. nomadica is limited to the Israeli coastline, or whether it is spreading into other parts of the Mediterranean.

We attempted to verify the macrodistribution of Rhopilema nomadica by obtaining data, using detailed questionnaires, from marine stations along the Mediterranean. Responses to this questionnaire were received from $70 \%$ of the countries, providing at least 1 detailed answer (see Table 2). Negative answers concerning any records of Rhopilema nomadica were received from all the countries surrounding the western basin of the Mediterranean, the Turkish coast, Cyprus, and the Aegean Sea, as well as the Egyptian coastline.

Aggregations of Rhopilema nomadica have been observed along the coasts of Lebanon since the summer of 1988 (Lakkis \& Zeidane 1991). By 1991, the estimated population size in Lebanon was equal to that of Haifa Bay (see Table 3). Aggregation of $R$. nomadica has also been observed in the coastal waters of Syria (based on the answer to the questionnaire from Tichreen University at Lattakia). However, the population density of $R$. nomadica along the Syrian coast during 1991 was lower than the densities observed near the Israeli and Lebanese coasts $15.7 \times 10^{3} \mathrm{~km}^{-2}$ in Syria, as compared with $1.6 \times 10^{5}$ in Israel).

A total of $500 \mathrm{~km}$ of coastal water was colonized by the medusa during a $14 \mathrm{yr}$ period (Fig. 5). The direction of medusa dispersal is from south to north, and the jellyfish is probably transported northwards by the prevailing counterclockwise currents of the southeastern Mediterranean (Almagor \& Hall 1984). The continental margin of southern Israel and Egypt is regarded as the northeastern extension of the Nile Delta, and is characterized by sandy sediments (Almagor \& Hall 1984). Therefore, the absence of Rhopilema nomadica from the coastal waters of Egypt might be due to the lack of sufficient rocky substrates necessary for polyp settlement. The absence of $R$. nomadica from the coastal waters of Cyprus (less than $180 \mathrm{~km}$ from Lebanon), may indicate that deep water acts as a barrier to the continuous dispersal of the medusa.

Table 2. Rhopilema nomadica. Occurrence throughout the Mediterranean in 1992. Data based on responses of the institution listed to a questionnaire

\begin{tabular}{|c|c|c|c|}
\hline Institution & Locality & Winter temperature $\left({ }^{\circ} \mathrm{C}\right)$ & Occurrence \\
\hline \multirow{3}{*}{$\begin{array}{l}\text { Muséum National d'Histoire Naturelle, Paris, France } \\
\text { Marine Laboratorio E Pesca, Fano, Italy } \\
\text { Instituto Scienze Ambientali Marine, } \\
\text { Universita di Genova, Italy }\end{array}$} & Ligurian Sea & 12.7 & - \\
\hline & Adriatic Sea & 12.3 & - \\
\hline & Genoa & 13.7 & - \\
\hline Center of Marine Research, Rovinj, Croatia & Adriatic Sea & 12.7 & - \\
\hline University of Valletta, Valletta, Malta & Central Mediterranean & 16.0 & - \\
\hline National Center for Marine Research, & Ionian Sea & 14.2 & - \\
\hline \multirow[t]{4}{*}{ Athens, Greece } & Aegean Sea & 14.5 & - \\
\hline & Levantine Sea & & - \\
\hline & Crete Sea & & - \\
\hline & Libyan Sea & & - \\
\hline Department of Fisheries, Nicosia, Cyprus & Levantine Sea & 16.5 & - \\
\hline MED POL (pers comm.), Bingel (1991); Turkey & Levantine Sea & 16.0 & - \\
\hline $\begin{array}{l}\text { Marine Research Institute, Tichreen University, } \\
\text { Lattakia, Syria }\end{array}$ & Eastern Mediterranean & 16.7 & + \\
\hline Marine Research Center, Jounieh, Lebanon & Eastern Mediterranean & 16.7 & + \\
\hline Tel Aviv University, Tel Aviv, Israel & Eastern Mediterranean & 16.7 & + \\
\hline Faculty of Science, Alexandria, Egypt & Southern Mediterranean & 17.0 & - \\
\hline
\end{tabular}


Table 3. Chronology of range extension of Rhopilema nomadica

\begin{tabular}{|c|c|c|c|}
\hline Year & Locality & Event & Density \\
\hline 1977 & Israel & First report ${ }^{\mathrm{d}}$ & Few individuals \\
\hline 1986 & Israel & Large aggregations ${ }^{b}$ & Not detected \\
\hline 1989 & Israel & Large aggregations ${ }^{c}$ & $1.6 \times 10^{5} \mathrm{~km}^{-2}$ \\
\hline 1988 & Lebanon & First report ${ }^{d}$ & Not detected \\
\hline 1991. & Lebanon & Large aggregations & $10^{6} \mathrm{~km}^{-2}$ \\
\hline 1991 & Syria & Northernmost limit & $5.7 \times 10^{3} \mathrm{~km}^{-2}$ \\
\hline \multicolumn{2}{|c|}{$\begin{array}{l}{ }^{\mathrm{a}} \text { Galil et al. (1990) } \\
{ }^{\mathrm{b}} \text { Reports in the } \\
\text { popular press } \\
{ }^{\mathrm{C}} \text { Lotan et al. (1992) }\end{array}$} & \multicolumn{2}{|c|}{ 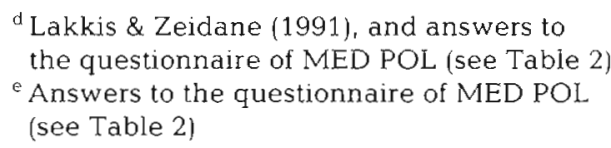 } \\
\hline
\end{tabular}

Based on this study, low winter temperatures in shallow waters are expected to be the main barrier to range extension of Rhopilema nomadica westward beyond Greece (Table 2). Jellyfish migration by ballast water

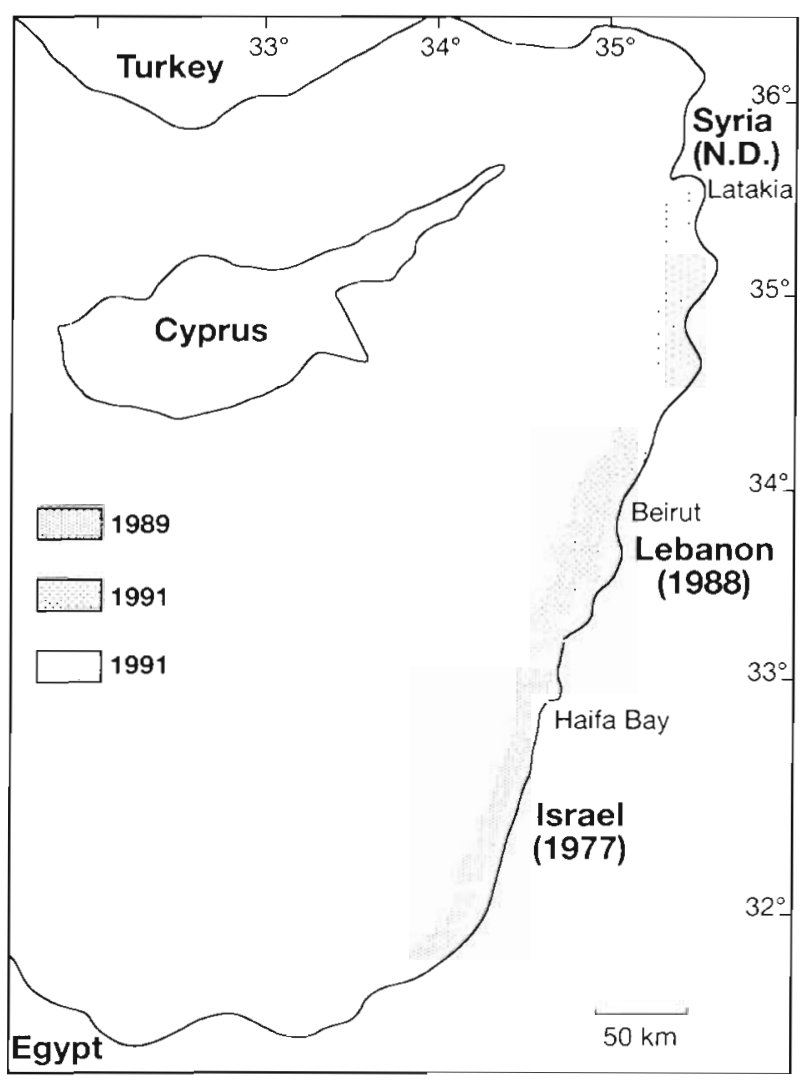

Fig 5. Rhopilema nomadica. Northward migration along the eastern Mediterranean, during the years 1977 to 1991. Dates in brackets represent the first record of $R$. nomadica from the Israeli and Lebanese coasts. Large aggregations of the medusae have been observed near the Israeli coast since the summer of 1989, while the same densities appeared on the Lebanese coast only in $1991\left(10^{6}\right.$ specimens $\left.\mathrm{km}^{-2}\right)$. Smaller aggregations of the medusae $\left(10^{3}\right.$ specimens $\left.\mathrm{km}^{-2}\right)$ were counted north of Lebanon in Syria N.D : not detected was described by Carlton (1985). The dispersal of $R$. nomadica through ballast water to the southwestern parts of the Levant Basin (Libya, Egypt), where temperature conditions are appropriate, may eventually occur despite the anticlockwise current along the Levant coast.

A detailed survey of ballast water migrations has revealed colonization by Indo-Pacific scyphomedusae into areas with temperate climate, whereas no representatives of this group have yet been recorded migrating from the IndoPacific to cold water seas (Carlton 1985). In a similar manner, 2 Indo-Pacific scyphomedusae have colonized the Levant Basin (Galil et al. 1990). The ephyra or scyphistoma stages of the jellyfish life cycle enable such migrations via ballast water (Carlton 1985, Lotan et al. 1992). However, at present, the dispersal pattern of the new colonies of medusae is restricted to areas in which water temperatures resemble those of the Indo-Pacific. Therefore, we suggest water temperature as a universal limiting factor for migration of Indo-Pacific scyphomedusae into non-tropical seas.

Acknowledgements. Special thanks to Dr G. P. Gabrielides from UNEP for his help with the coordination of the questionnaire and to all the scientists who answered it. We thank $\mathrm{Mr}$ M. Fainzilber and Dr R. Lotan for their comments on the manuscript and the Israel Oceanographic \& Limnological Research, National Institute of Oceanography for their technical assistance. Finally we thank 3 anonymous reviewers for their helpful and constructive comments. This work has been partially supported by the UNEP Mediterranean Action Plan and by the Israeli Ministry of the Environment.

\section{LITERATURE CITED}

Almagor, G., Hall, J. K. (1984). Morphology of the Mediterranean continental margin of Israel. Isr. Geol. Surv. Bull. 77: 1-31

Axiak, V., Galea, C., Schembri, P. J. (1991). Coastal aggregations of the jellyfish Pelagia noctiluca (Scyphozoa) in Maltese coastal waters during 1980-1986. In: Jellyfish blooms in the Mediterranean. Proceedings of the II Workshop on Jellyfish in the Mediterranean Sea. Map Technical Reports Series no. 47. UNEP, Athens, p. 32-40

Azov, Y (1991). Eastern Mediterranean - a marine desert? Mar. Pollut. Bull. 23: 225-232

Bingel, F., Avsar, D., Gucu, A. C. (1991). Occurrence of jellyfish in Mersin Bay. In:Jellyfish blooms in the Mediterranean. Proceedings of the II Workshop on Jellyfish in the Mediterranean Sea. Map Technical Reports Series no. 47. UNEP, Athens, p. 65-71

Brewer, H. R. (1989). The annual pattern of feeding, growth, and sexual reproduction in Cyanea (Cnidaria: Scyphozoa) in the Niantic River Estuary, Connecticut. Biol. Bull. 176: $272-281$

Calder, D. R. (1974). Strobilation of the sea nettle, Chrysaora quinquecirrha, under field conditions. Biol. Bull. 146: $326-334$ 
Carlton, T. J. (1985). Transoceanic and interoceanic dispersal of coastal marine organisms: the biology of ballast water Oceanogr. mar. Biol. A. Rev. 23: 313-371

Chen, J., Ding, G. (1984). On the seasonal regulatory of the strobilation of edible medusa. Shui Chan Xue Bao (J. Fish China) 8(1): $55-68$

Chen, J., Ding, G., Liu, C. (1985). Effect of nutritional conditions on the strobilation of edible medusa, Rhopilema esculanta Kishinouye. Shui Chan Xue Bao (J. Fish. China) 9(4): $321-328$

Galil, B. S., Spanier, E., Ferguson, W. W. (1990). The scyphomedusae of the Mediterranean coast of Israel, including two lessepsian migrants new to the Mediterranean. Zool Meded. Leiden 64: 95-106

Goy, J., Morand, P., Etienne, M. (1989). Long term fluctuations of Pelagia noctiluca (Cnidaria, Scyphomedusa) in the western Mediterranean Sea. Prediction by climatic variables. Deep Sea Res. 36(2): 269-280

Hernroth, L., Grondahl, F. (1983). On the biology of Aurelia aurita (L.) 1. Release and growth of Aurelia aurita (L.) ephyrae in the Gullmar Fjord, Western Sweden, 1982-3. Ophelia 22(2): 189-199

Hernroth, L., Grondahl, F. (1985). On the biology of Aurelia aurita (L.). 2. Major factors regulating the occurrence of ephyrae and young medusae in the Gullmar Fjord, Western Sweden. Bull. mar. Sci. 37(2): 567-576

Lakkis, S. (1991). Aggregations of the scyphomedusa Rhizostoma pulmo in the Lebanese coastal waters during the summer of 1986. In: Jellyfish blooms in the Mediterranean. Proceedings of the II Workshop on jellyfish in the Mediterranean Sea. Map Technical Reports Series no. 47. UNEP, Athens, p. 119-127

Lakkis, S., Zeidane, R. (1991). Jellyfish swarm along the Lebanese coast. (Abstract.) Lebanese Association for Ad-

This article was submitted to the editor vancement of Sclence 11 th Science Meeting, American University of Beirut

Larson, R. J. (1986). The feeding and growth of the sea nettle, Chrysaora quinquecirrha (Desor) in the laboratory. Estuaries 9(4B): $376-379$

Legovic, $T$ (1987). A recent increase in jellyfish populations: a predator-prey model and its implications. Ecol. Model. 38: $243-256$

Lotan, A., Ben-Hillel, R., Loya, Y (1992). Life: cycle of Rhopilema nomadica: a new immigrant scyphomedusan in the Mediterranean. Mar Biol. 112: 237-242

Möller, H. (1980) Population dynamics of Aurelia aurita medusae in Kiel Bight, Germany (FRG). Mar. Biol. 60: $123-128$

Muscatine, L., Matian, R. E. (1982). Dissolved inorganic nitrogen flux in symbiotic and nonsymbiotic medusae. Limnol. Oceanogr. 27(5): $910-917$

Naval Oceanographic Office (1989). Data base description for master generalized digital environmental model (GDEM). Technical report OAML-DBD-20B. Environmental System Division, Stennis Space Center, Bay St. Louis, MS

Oren, O. H., Hornung, H. (1972). Temperatures and salinities off the Israeli Mediterranean coast. Sea. Fish. Res. Stn Haifa Bull. 59: 17-31

Sokal, R. R., Rohlf, F.J. (1969). Biometry. W. H. Freeman and Company, San Francisco

Wilkerson, F. P., Dugdale, R. C. (1983). Possible connection between sewage effluent, nitrogen levels and jellyfish blooms. In: Jellyfish blooms in the Mediterranean. Proceedings of the II Workshop on Jellyfish in the Mediterranean sea. Map Technical Reports Series no. 47. UNEP, Athens, p. 295-201

Zavodnik, D. (1987). Spatial aggregations of the swarming jellyfish Pelagia noctiluca (Scyphozoa). Mar. Biol. 94: $265-269$

Manuscript first received: September 21, 1993

Revised version accepted: March 14, 1994 